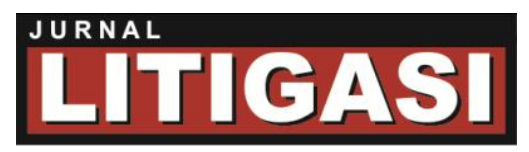

Available online at: http://ejournal.unpas.ac.id/index.php/litigasi

Litigasi, Vol. 16(1), 2015, 2781-2804

DOI: http://dx.doi.org/10.23969/litigasi.v16i1.53

\title{
PENGADAAN TANAH DENGAN CARA JUAL BELI OLEH INSTANSI PEMERINTAH MENURUT PASAL 33 AYAT (3) UUD 1945
}

\author{
Dedy Hernawan
}

Dosen Fakultas Hukum Universitas Pasundan, Jl. Lengkong Besar No. 68 Bandung 40261, Telp: 022 4262226, Fax: 022-4217340, Hp: 08122377982 E-mail: dedy.hernawan@unpas.ac.id

\begin{abstract}
ABSTRAK
Pembangunan sarana prasarana fisik memerlukan ketersediaan tanah, baik tanah negara dan tanah hak. Pengadaan tanah dalam skala kecil yang luasnya kurang dari 5 (lima) hektar, dapat dilakukan dengan jual beli antara instansi pemerintah dengan pemilik tanah, tanahnya kemudian menjadi milik pemerintah atau pemerintah daerah. Penelitian ini membahas konsekuensi yuridis pelaksanaan pengadaan tanah bagi pembangunan untuk kepentingan umum dengan cara jual beli oleh instansi pemerintah dengan pemilik tanah menurut perundang-undangan, membahas cara yang seharusnya dilakukan oleh instansi pemerintah dalam pelaksanaan pengadaan tanah bagi pembangunan untuk kepentingan umum. Hasil penelitian mengenai konsekuensi yuridis pelaksanaan pengadaan tanah bagi pembangunan untuk kepentingan umum dengan cara jual beli sebagaimana diatur dalam UU No. 2 Tahun 2012 tentang Pengadaan Tanah Bagi Pembangunan Untuk Kepentingan Umum, Perpres No. 40 tahun 2014 yang mengakibatkan tanah tersebut menjadi tanah milik pemerintah/pemerintah daerah adalah bertentangan dengan ketentuan yang diatur dalam Pasal 33 ayat (3) UUD 1945 dan ketentuan UUPA No. 5 Tahun 1960. Cara yang seharusnya bagi pembangunan untuk kepentingan umum yang sesuai dengan Pasal 33 ayat (3) UUD 1945 adalah melalui proses pelepasan hak dan/atau pencabutan hak dengan pemberian ganti rugi, seyogyanya besaran ganti rugi tersebut didasarkan pada nilai harga jual beli bukan berdasarkan nilai jual objek pajak.
\end{abstract}

Kata kunci : tanah, jual beli, pelepasan hak.

Copyright @ 2015, LITIGASI, p-ISSN: 0853-7100; e-ISSN: 2442-2274 
Available online at: http://ejournal.unpas.ac.id/index.php/litigasi

Litigasi, Vol. 16(1), 2015, 2781-2804

DOI: http://dx.doi.org/10.23969/litigasi.v16i1.53

\begin{abstract}
The Development of physical infrastructure always requires the availability of land, it is not limited to the State land but also to the land rights. Small-scale land acquisition in the area of less than five (5) acre, can be bought or sold between government agencies with land owners, then the land belongs to the government or local government. This provision is problematic because according to Indonesian laws, the land is controlled by the State instead of owned. The writer will conduct the research with the aim of knowing the Judicial consequences of the implementation of land for development in the public interest by sale and purchase as stipulated in the laws. Knowing supposed to be done by government institution in order to land acquisition for public development. From the research it can be concluded that: Knowing the Judicial consequences of the implementation of land for development in the public interest by sale and purchase as stipulated in the law number 2 year 2012 on procurement land for development for public interest, presidential decree number 40 year 2014 which resulted in the land of inheritance of government, is contrary to the provision set forth in article 33 paragraph 3 of the constitution 1945 and the provision of the basic law of agrarian number 5 year 1960. The supposed to be done by government institution in order to land acquisition for public development is trough waiver process/or extraction right by compensation, the amount of compesation itself supposed to be based on the price not based on the tax value of the land.
\end{abstract}

Keywords: land, buying and selling, waiver.

Copyright @ 2015, LITIGASI, p-ISSN: 0853-7100; e-ISSN: 2442-2274 
Available online at: http://ejournal.unpas.ac.id/index.php/litigasi

Litigasi, Vol. 16(1), 2015, 2781-2804

DOI: http://dx.doi.org/10.23969/litigasi.v16i1.53

\section{PENDAHULUAN}

Pesatnya serta keragaman pembangunan yang terjadi, ternyata dihadapkan pada persoalan-persoalan seperti yang berkaitan dengan pemanfaatan lahan, yang diantaranya adalah (Juniarso Ridwan dan Achmad Sodik, 2007):

1. Terbatasnya lahan yang tersedia dengan berbagai fungsi peruntukan;

2. Pemanfaatan dan pengelolaan lahan serta pola tata ruang yang belum sepenuhnya dilaksanakan secara terpadu dan menyeluruh;

3. Penggunaan lahan seringkali terjadi penyimpangan dari peruntukannya;

4. Persaingan mendapatkan lokasi lahan yang tidak didukung atau yang berdekatan dengan berbagai fasilitas perkotaan sebagai akibat dan pengaruh perkembangan kota;

5. Masih rendahnya kesadaran hukum masyarakat terhadap kepatutan atas kewajiban sebagai warga negara.

Pertumbuhan penduduk yang tinggi di perkotaan akibat arus dari urbanisasi menyebabkan pengelolaan ruang kota menjadi semakin berat. Kepadatan penduduk yang demikian besar tersebut merupakan salah satu permasalahan dan menjadi isu penting dalam pelaksanaan manajemen perkotaan. Isu dari kependudukan yang meningkat tinggi akan menjadi masalah, pada saat pertumbuhannya melebihi kapasitas penyediaan sistem pelayanan perkotaan seperti jaringan jalan, air bersih, pengelolaan sampah, penyediaan pemukiman, dan masalah-masalah lingkungan lainnya.

Copyright $\odot$ 2015, LITIGASI, p-ISSN: 0853-7100; e-ISSN: 2442-2274 
Available online at: http://ejournal.unpas.ac.id/index.php/litigasi

Litigasi, Vol. 16(1), 2015, 2781-2804

DOI: http://dx.doi.org/10.23969/litigasi.v16i1.53

Tidak seimbangnya prasarana dan sarana perkotaan dibandingkan dengan kebutuhan akan menimbulkan ketidakefektifan dan ketidakefesienan dalam penggunaan dan pemakaian prasarana dan sarana yang tersedia.

Lahan perkotaan yang relatif terbatas itu cenderung sangat tidak seimbang dibandingkan dengan pemanfaatannya akan mengakibatkan perkembangan kota menjadi semakin tidak terkendali dan kualitas hidup dan kenyamanan di daerah perkotaan akan semakin terganggu. Lemahnya penegakan hukum mengenai pemanfaatan ruang kota telah menimbulkan berbagai macam persoalan, diantaranya adalah banyaknya kawasan perkotaan di Indonesia yang mengalami banjir pada saat musim hujan atau kekeringan pada musim kemarau. Kondisi tersebut pada dasarnya diakibatkan selain terbatasnya lahan di kawasan perkotaan juga banyaknya lahan-lahan hijau yang terbangun dan menyalahi peruntukannya.

Berdasarkan uraian tersebut, aspek pertanahan guna penyediaan lahan dan penataan ruang sangat perlu dan mutlak untuk dipertimbangkan, karena tanah merupakan salah satu sumber daya kegiatan baik masyarakat maupun pemerintah yang dapat dinilai sifat, keadaan, proses dan penggunaannya.

Upaya Pemerintah untuk memenuhi keperluan akan tanah tersebut diwujudkan antara lain dengan lahirnya Undang-Undang No. 2 Tahun 2012 tentang Pengadaan Tanah Bagi Pembangunan Untuk Kepentingan Umum (Selanjutnya disebut Undang-Undang Pengadaan Tanah).

Copyright @ 2015, LITIGASI, p-ISSN: 0853-7100; e-ISSN: 2442-2274 
Available online at: http://ejournal.unpas.ac.id/index.php/litigasi

Litigasi, Vol. 16(1), 2015, 2781-2804

DOI: http://dx.doi.org/10.23969/litigasi.v16i1.53

Pasal 11 ayat (1) Undang-Undang Pengadaan Tanah mengatur bahwa: pengadaan tanah untuk kepentingan umum sebagaimana dimaksud dalam Pasal 10 wajib diselenggarakan oleh pemerintah dan tanahnya selanjutnya dimiliki pemerintah atau pemerintah daerah.

Pasal 27 Undang-Undang Pengadaan Tanah ayat (3) dan ayat (4) mengatur sebagai berikut :

(3) Setelah penetapan lokasi pembangunan untuk kepentingan umum sebagaimana dimaksud dalam Pasal 26 ayat (1), pihak yang berhak hanya dapat mengalihkan hak atas tanahnya kepada instansi yang memerlukan tanah melalui lembaga pertanahan.

(4) Beralihnya hak sebagaimana dimaksud pada ayat (3) dilakukan dengan memberikan ganti kerugian yang nilainya ditetapkan saat nilai pengumuman penetapan lokasi.

Pasal 33 ayat (3) UUD 1945, mengatur bahwa : Bumi, air dan kekayaan alam yang terkandung di dalamnya dikuasai oleh negara dan dipergunakan untuk sebesar-besarnya kemakmuran rakyat.

Arti perkataan "dikuasai" yang dipergunakan dalam pasal 33 ayat (3) Undang- Undang Dasar 1945 bukanlah berarti "dimiliki" akan tetapi pengertian yang memberi wewenang kepada negara sebagai organisasi kekuasaan dari bangsa Indonesia untuk:

1. Mengatur dan menyelenggarakan peruntukan, penggunaan, persediaan dan pemeliharaan bumi, air dan ruang angkasa;

Copyright @ 2015 , LITIGASI, p-ISSN: 0853-7100; e-ISSN: 2442-2274 
Available online at: http://ejournal.unpas.ac.id/index.php/litigasi

Litigasi, Vol. 16(1), 2015, 2781-2804

DOI: http://dx.doi.org/10.23969/litigasi.v16i1.53

2. Menentukan dan mengatur hubungan-hubungan hukum antara orangorang dengan bumi, air dan ruang angkasa;

3. Menentukan dan mengatur hubungan-hubungan hukum antara orang dan perbuatan-perbuatan hukum mengenai bumi, air dan ruang angkasa.

Berdasarkan uraian permasalahan tersebut, maka menarik penulis untuk melakukan pengkajian terhadap konsep teori dasar hukum pertanahan, khususnya mengenai pengadaan tanah untuk proses kegiatan pembangunan. Penelitian ini difokuskan terhadap konsekuensi yuridis pelaksanaan pengadaan tanah bagi pembangunan untuk kepentingan umum dengan cara jual beli oleh instansi pemerintah dengan pemilik tanah, dan model atau cara apakah yang seharusnya dilakukan oleh pemerintah dalam pelaksanaan pengadaan tanah bagi pembangunan untuk kepentingan umum.

Berdasarkan uraian pada latar belakang masalah tersebut, maka penulis merumuskan identifikasi masalah sebagai berikut : Bagaimanakah konsekuensi yuridis pelaksanaan pengadaan tanah bagi pembangunan untuk kepentingan umum dengan cara jual beli oleh instansi pemerintah dengan pemilik tanah menurut Undang-Undang No. 2 Tahun 2012, Perpres No. 40 Tahun 2014 dihubungkan dengan Pasal 33 ayat (3) UUD 1945 ? Cara apakah yang seharusnya dilakukan oleh instansi pemerintah dalam pelaksanaan pengadaan tanah bagi pembangunan untuk kepentingan umum yang sesuai dengan Pasal 33 ayat (3) UUD 1945 ?

Copyright $\odot$ 2015, LITIGASI, p-ISSN: 0853-7100; e-ISSN: 2442-2274 
Available online at: http://ejournal.unpas.ac.id/index.php/litigasi

Litigasi, Vol. 16(1), 2015, 2781-2804

DOI: http://dx.doi.org/10.23969/litigasi.v16i1.53

\section{PEMBAHASAN}

A. Konsekuensi Yuridis Pelaksanaan Pengadaan Tanah Bagi Pembangunan Untuk Kepentingan Umum Dengan Cara Jual Beli Oleh Instansi Pemerintah Dengan Pemilik Tanah Menurut UU No. 2 Tahun 2012, Perpres No. 40 Tahun 2014 Dihubungkan Dengan Pasal 33 Ayat (3) UUD 1945

Negara sebagai pemegang hak menguasai atas tanah memiliki hak untuk membuat kebijakan yang mengatur tentang kepentingan umum atas tanah, semata-mata untuk mencapai kehidupan yang lebih baik bagi masyarakatnya. Kebijakan tersebut harus didasari oleh asas-asas hukum umum dalam pokok-pokok pikiran pembukaan UUD 1945. Hal itu berarti bahwa penggunaan tanah atas dasar kepentingan umum dipengaruhi oleh nilai, norma serta asas-asas hukum dan pelaksanaannya diatur di dalam peraturan serta keputusan - keputusan, dengan tetap memperhatikan sifat normatif dalam mempertimbangkan kenyataan secara optimal.

Penerapan fungsi sosial menekankan pada suatu kewajiban yang pelaksanaannya dituntut dari pihak yang memiliki, menggunakan atau mengerjakan tanah (misalnya, pihak ketiga). Kewajiban itu merupakan penghubung antara arti fungsi sosial di satu pihak dan kepentingan umum dipihak lain. Dalam UUPA fungsi sosial atas tanah diatur dalam Pasal 6 dan dalam Penjelasan Umum nomor II angka 4.

Copyright @ $\odot$ 2015, LITIGASI, p-ISSN: 0853-7100; e-ISSN: 2442-2274 
Available online at: http://ejournal.unpas.ac.id/index.php/litigasi

Litigasi, Vol. 16(1), 2015, 2781-2804

DOI: http://dx.doi.org/10.23969/litigasi.v16i1.53

Berdasarkan ketentuan tersebut dapatlah diambil suatu kesimpulan bahwa fungsi sosial yang melekat pada hak atas tanah merupakan fungsi yang dipunyai oleh pemegang haknya sekaligus juga mempunyai fungsi kemasyarakatan. Konsekuensinya adalah dalam penggunaan tanah harus memperhatikan dua kepentingan yaitu kepentingan pemegang hak dan kepentingan masyarakat. Kedua kepentingan tersebut harus seimbang yang artinya tidak boleh merugikan kepentingan masyarakat dan begitupun sebaliknya bahwa kepentingan masyarakat tidak boleh merugikan kepentingan pemegang hak.

Hak menguasai negara atas tanah harus bermuara pada satu tujuan Iuhur yakni menciptakan sebesar-besar kemakmuran rakyat. Salah satu bentuk hak menguasai negara atas tanah yang ada kaitannya dengan hakhak perorangan yaitu negara memiliki kewenangan untuk melaksanakan pembangunan untuk kepentingan umum melalui pelepasan hak dan pencabutan hak-hak atas tanah dan benda-benda di atasnya.

Ketika negara membutuhkan tanah untuk kepentingan umum sehingga harus melaksanakan pelepasan hak atau pencabutan hak atas tanah milik masyarakat, maka negara harus memperhatikan dan mempertimbangkan prinsip-prinsip keseimbangan antara kepentingan perseorangan, masyarakat dan negara sehingga hak-hak dari pemegang hak atas tanah tersebut dapat terlindungi secara hukum karena negara 
Available online at: http://ejournal.unpas.ac.id/index.php/litigasi

Litigasi, Vol. 16(1), 2015, 2781-2804

DOI: http://dx.doi.org/10.23969/litigasi.v16i1.53

mengakui adanya hak perseorangan atas tanah sebagai hak dasar manusia atas sumber daya alam.

Faktor-faktor penting yang perlu dipertimbangkan dalam pengadaan tanah bagi pembangunan untuk kepentingan umum adalah :

a. Pengadaan tanah harus memenuhi syarat tata ruang dan tata guna tanah.

b. Pengadaan tanah tidak boleh mengakibatkan kerusakan atau pencemaran terhadap kelestarian alam dan lingkungan.

c. Pengadaan tanah tidak boleh mengakibatkan kerugian bagi pemilik tanah.

Pada asasnya, jika diperlukan tanah atau benda-benda lainnya kepunyaan orang lain untuk sesuatu keperluan pembangunan proyekproyek pemerintah haruslah lebih dahulu diusahakan agar tanah itu dapat diperoleh dengan persetujuan pemilik tanah, melalui pelepasan hak. Tetapi apabila cara demikian tidak berhasil, karena ada kemungkinan pemilik tanah meminta harga atau ganti rugi yang terlampau tinggi atau tidak bersedia sama sekali untuk melepaskan tanah yang diperlukan itu, maka untuk kepentingan pembangunan yang pada hakikatnya demi kepentingan umum harus lebih didahulukan daripada kepentingan orang perseorangan. Jika pembangunan tersebut benar-benar untuk kepentingan umum, dan dalam musyawarah tidak membawa hasil yang diharapkan untuk dapat mengambil dan menguasai tanah yang 
Available online at: http://ejournal.unpas.ac.id/index.php/litigasi

Litigasi, Vol. 16(1), 2015, 2781-2804

DOI: http://dx.doi.org/10.23969/litigasi.v16i1.53

bersangkutan, pemerintah dapat melakukan pencabutan hak atas tanah tersebut. Pemerintah dapat melakukan pencabutan hak atas tanah sebagaimana dimaksud dalam ketentuan Pasal 18 UUPA, yang menyebutkan bahwa, "Untuk kepentingan umum, termasuk kepentingan bangsa dan negara serta kepentingan bersama dari rakyat, hak-hak atas tanah dapat dicabut dengan memberikan ganti kerugian yang layak dan menurut cara yang diatur dengan undang-undang".

Apabila tanah yang diperlukan oleh pemerintah untuk kegiatan pembangunan tersebut luasnya kurang dari 5 (lima) hektar, dapat dilakukan melalui jual beli. Hal tersebut sesuai dengan ketentuan Pasal 121 Peraturan Presiden No. 40 Tahun 2014 tentang Pengadaan Tanah Skala Kecil, yang mengatur :

"Dalam rangka efisiensi dan efektivitas, pengadaan tanah untuk kepentingan umum yang luasnya tidak lebih dari 5 (lima) hektar dapat dilakukan langsung oleh instansi yang memerlukan tanah dengan para pemegang hak atas tanah, dengan cara jual-beli atau tukar menukar atau cara lain yang disepakati oleh kedua belah pihak".

Ketentuan seperti hal tersebut di atas dapat dijumpai pula pada

Pasal 54 Peraturan Kepala Badan Pertanahan Nasional Republik

Indonesia Nomor 3 tahun 2007 tentang Ketentuan Pelaksanaan

Peraturan Presiden Nomor 36 tahun 2005 tentang Pengadaan Tanah Bagi Pelaksanaan Pembangunan Untuk Kepentingan Umum sebagaimana

Copyright $@$ 2015, LITIGASI, p-ISSN: 0853-7100; e-ISSN: 2442-2274 
Available online at: http://ejournal.unpas.ac.id/index.php/litigasi

Litigasi, Vol. 16(1), 2015, 2781-2804

DOI: http://dx.doi.org/10.23969/litigasi.v16i1.53

telah diubah dengan Peraturan Presiden Nomor 65 tahun 2006 tentang Perubahan Atas Peraturan Presiden Nomor 36 tahun 2005.

Melihat pada peraturan sebelumnya, ketentuan tersebut pernah diatur pada Pasal 23 Keputusan Presiden No. 55 Tahun 1993 dan Pasal 20 Peraturan Presiden No. 36 Tahun 2005, serta Pasal 23 Perpres No. 65 Tahun 2006.

Setelah proses jual beli dilakukan maka tanah tersebut akan menjadi tanah milik pemerintah atau pemerintah daerah tergantung siapa yang melakukan pembelian tanah tersebut.

Setelah proses jual beli dilakukan maka tanah tersebut akan menjadi tanah milik pemerintah atau pemerintah daerah tergantung siapa yang melakukan pembelian tanah tersebut. Hal tersebut diatur sebagaimana diatur pada Pasal 11 ayat (1) Undang-Undang No. 2 Tahun 2012 tentang Pengadaan Tanah Bagi Pembangunan Untuk Kepentingan Umum yang mengatur bahwa, "Pengadaan tanah untuk kepentingan umum sebagaimana dimaksud dalam Pasal 10 wajib diselenggarakan oleh pemerintah dan tanahnya selanjutnya dimiliki pemerintah atau pemerintah daerah".

Menurut ketentuan Pasal 27 ayat (3) UU No. 2 Tahun 2012 bahwa, "setelah penetapan lokasi pembangunan untuk kepentingan umum, pihak yang berhak hanya dapat mengalihkan hak atas tanahnya

Copyright @ $\odot$ 2015, LITIGASI, p-ISSN: 0853-7100; e-ISSN: 2442-2274 
Available online at: http://ejournal.unpas.ac.id/index.php/litigasi

Litigasi, Vol. 16(1), 2015, 2781-2804

DOI: http://dx.doi.org/10.23969/litigasi.v16i1.53

kepada instansi yang memerlukan tanah". "Beralihnya hak atas tanah tersebut dilakukan dengan memberikan ganti rugi" (Pasal 27 ayat (4)).

Tercantum dalam ketentuan UUPA, berpindahnya hak-hak atas tanah dari pemilik semula kepada pihak lain berbeda dengan hapusnya hak-hak atas tanah. Berpindahnya hak atas tanah dapat dilakukan melalui peralihan hak. Peralihan hak terdiri atas beralih dan dialihkan.

Beralih artinya berpindahnya hak atas tanah dari pemiliknya kepada pihak lain karena terjadinya suatu peristiwa hukum, misalnya meninggalnya pemilik tanah mengakibatkan hak atas tanahnya berpindah secara hukum kepada ahli warisnya sepanjang ahli warisnya tersebut memenuhi syarat sebagai subjek hak atas tanah.

Pengertian dialihkan ialah berpindahnya hak atas tanah dari pemiliknya kepada pihak lain karena terjadinya suatu perbuatan hukum, misalnya jual beli, tukar menukar, hibah dan sebagainya.

Berdasarkan dari uraian tersebut di atas dapat dikemukakan bahwa ciri pokok pada peralihan hak atas tanah adalah terjadinya perpindahan hak dari pemilik atau pemegang hak atas tanah semula kepada pemilik atau pemegang hak atas tanah berikutnya.

Tercantum dalam ketentuan UUPA peralihan hak-hak atas tanah diatur pada pasal-pasal dibawah ini :

a) Peralihan hak milik diatur pada Pasal 20 ayat (2) yang menyatakan bahwa, "hak milik dapat beralih dan dialihkan kepada pemilik lain.

Copyright @ C 2015, LITIGASI, p-ISSN: 0853-7100; e-ISSN: 2442-2274 
Available online at: http://ejournal.unpas.ac.id/index.php/litigasi

Litigasi, Vol. 16(1), 2015, 2781-2804

DOI: http://dx.doi.org/10.23969/litigasi.v16i1.53

b) Peralihan hak guna usaha, diatur pada Pasal 28 ayat (3) yang menyebutkan bahwa : "hak guna usaha dapat beralih dan dialihkan kepada pihak lain".

c) Peralihan hak guna bangunan, diatur pada Pasal 28 ayat (3) yang menyebukan bahwa : "hak guna bangunan dapat beralih dan dialihkan kepada pihak lain.

Peralihan hak pakai, ketentuan hak pakai dalam UUPA terdapat selain pada Pasal 16 ayat (1) huruf $d$, secara khusus diatur dalam Pasal 41 sampai dengan Pasal 43, dan Pasal 50 ayat (2) lebih lanjut mengenai hak-hak pakai diatur dengan peraturan perundang-undangan. Peraturan perundang-undangan yang dimaksud adalah peraturan pemerintah No. 40 Tahun 1996, yang secara hukum diatur pada Pasal 39 sampai dengan 58.

Ketentuan Pasal 11 ayat (1), Pasal 27 ayat (3) dan Pasal 27 ayat (4) Undang-Undang No. 2 tahun 2012 tentang Pengadaan Tanah dan ketentuan tentang pengadaan tanah dengan cara jual beli yang diatur dalam Perpres No. 40 tahun 2014, menurut pendapat penulis dapat menimbulkan persoalan hukum. Masalah hukum yang dimaksud adalah adanya akibat hukum dari jual beli terhadap tanah sudah barang tentu akan terjadi perpindahan hak kepemilikan atas tanah. Dengan kata lain tanah yang dibeli oleh instansi pemerintah akan menjadi tanah milik dari instansi pemerintah tersebut.

Copyright @ C 2015, LITIGASI, p-ISSN: 0853-7100; e-ISSN: 2442-2274 
Available online at: http://ejournal.unpas.ac.id/index.php/litigasi

Litigasi, Vol. 16(1), 2015, 2781-2804

DOI: http://dx.doi.org/10.23969/litigasi.v16i1.53

Konsepsi negara sebagai pemilik tanah sebagaimana yang diatur dalam ketentuan Undang-Undang No. 2 Tahun 2012, Perpers No. 40 Tahun 2014 adalah tidak sesuai dengan filosofis negara Republik Indonesia, yaitu Pancasila. Konsepsi kepemilikan tanah oleh pemerintah juga tidak dianut baik dalam UUD 1945 maupun dalam UUPA, konsepsi yang dianut oleh keduanya adalah hak menguasai tanah oleh negara, sebagaimana yang diatur dalam ketentuan Pasal 33 ayat (3) UUD 1945 yang menyebutkan bahwa, "Bumi dan air dan kekayaan alam yang terkandung di dalamnya dikuasai oleh Negara dan dipergunakan untuk sebesar besar kemakmuran rakyat dan Pasal 2 ayat (1) dan ayat (2) UUPA, yang menyebutkan sebagai berikut :

Pasal 2 ayat (1) UUPA :

Bumi, air dan ruang angkasa termasuk kekayaan alam yang terkandung di dalamnya itu pada tingkatan tertinggi dikuasai oleh negara, sebagai organisasi kekuasaan seluruh rakyat.

Pasal 2 ayat (2) UUPA :

Hak menguasai negara, memberikan wewenang kepada negara untuk

(a) mengatur dan menyelenggarakan peruntukan, penggunaan, persediaan dan pemeliharaan bumi, air dan ruang angkasa;

(b) menentukan dan mengatur hubungan-hubungan hukum antara orang-orang dengan bumi, air dan ruang angkasa;

Copyright @ C 2015, LITIGASI, p-ISSN: 0853-7100; e-ISSN: 2442-2274 
Available online at: http://ejournal.unpas.ac.id/index.php/litigasi

Litigasi, Vol. 16(1), 2015, 2781-2804

DOI: http://dx.doi.org/10.23969/litigasi.v16i1.53

(c) menentukan dan mengatur hubungan-hubungan antara orangorang dengan perbuatan-perbuatan hukum yang mengenai bumi, air dan ruang angkasa.

Kewenangan negara tersebut, dilaksanakan untuk mencapai sebesar-besarnya kemakmuran rakyat dalam arti kebangsaan, kesejahteraan dan kemerdekaan dalam masyarakat dan negara Indonesia yang merdeka, berdaulat, adil dan makmur.

Hak menguasai negara merupakan suatu konsepsi yang mendasarkan pada pemahaman bahwa negara adalah suatu organisasi kekuasaan dari seluruh rakyat sehingga bagi pemilik kekuasaan, upaya mempengaruhi pihak lain menjadi sentral yang dalam hal ini dipegang oleh negara. Dalam kekuasaannya sebagai badan penguasa negara diberi tugas untuk menjalankan kewajiban terciptanya kemakmuran rakyat. Oleh karena itu, negara diberikan kewenangan yang bersifat dapat dipaksakan untuk mengatur penguasaan hak atas tanah.

Pengelolaan sumber daya alam yang dilakukan dan diusahakan oleh negara bermuara pada suatu tujuan yaitu terciptanya sebesarbesarnya kemakmuran rakyat. Tujuan itu menjadi tanggungjawab negara sebagai bentuk konsekuensi dari hak penguasaan negara terhadap bumi, air dan kekayaan alam yang terkandung di dalamnya.

Copyright @ C 2015, LITIGASI, p-ISSN: 0853-7100; e-ISSN: 2442-2274 
Available online at: http://ejournal.unpas.ac.id/index.php/litigasi

Litigasi, Vol. 16(1), 2015, 2781-2804

DOI: http://dx.doi.org/10.23969/litigasi.v16i1.53

Kewenangan negara dalam bidang pertanahan tersebut dilakukan oleh organ-organ penyelenggara negara, yaitu badan-badan pemerintahan dari pusat sampai ke daerah sedangkan sifat kewenangannya adalah bersifat publik semata.

Berdasarkan uraian tersebut di atas, menurut analisis penulis, pengadaan tanah untuk kegiatan pembangunan dengan cara jual beli sebagaimana diatur dalam Perpres No 40 tahun 2014 serta Pasal 11 ayat (1) Undang-undang No. 2 Tahun 2012 yang menjadikan instansi pemerintah sebagai pemilik tanah sangatlah bertentangan dengan ketentuan dalam Pasal 33 ayat (3) UUD 1945 dan ketentuan Pasal 2 UUPA tahun 1960.

B. Cara Yang Seharusnya Dilakukan Oleh Instansi Pemerintah Dalam Melakukan Pengadaan Tanah Bagi Pembangunan Untuk Kepentingan Umum Yang Sesuai Dengan Pasal 33 ayat (3) UUD 1945

Cara yang dikedepankan oleh pemerintah dalam melakukan pengadaan tanah adalah dengan memakai model pemberian ganti rugi, akan tetapi selama ini selalu tidak terdapat persamaan pandangan mengenai penetapan nilai ganti rugi antara masyarakat sebagai pemilik tanah dengan pemerintah. Masyarakat menghendaki nilai ganti rugi yang setinggi-tingginya dari harga pasaran atau paling tidak sesuai dengan harga pasaran, bahkan ada masyarakat yang menetapkan nilai ganti rugi

Copyright @ 2015, LITIGASI, p-ISSN: 0853-7100; e-ISSN: 2442-2274 
Available online at: http://ejournal.unpas.ac.id/index.php/litigasi

Litigasi, Vol. 16(1), 2015, 2781-2804

DOI: http://dx.doi.org/10.23969/litigasi.v16i1.53

tersebut didasarkan pada harga sekian tahun kedepan atau setelah pengadaan tanah dan/atau telah dijadikan sarana umum.

Dilain pihak pemerintah dalam menentukan nilai ganti rugi hanya berpatokan pada Nilai Jual Objek Pajak (NJOP) yang besarannya ditentukan oleh Kantor Pajak Bumi dan Bangunan. Berdasarkan realita, harga pasaran di masyarakat jauh lebih tinggi dari NJOP. Perbedaan NJOP dengan harga pasaran masih menjadi problematika dalam penentuan nilai ganti rugi pengadaan tanah. Pihak pemerintah berpatokan pada NJOP sedangkan masyarakat berpatokan pada harga pasaran.

Hakikatnya model pemberian ganti rugi yang diterapkan saat ini adalah satu-satunya model yang dapat diterima oleh masyarakat maupun pemerintah, namun yang menjadi permasalahan selanjutnya adalah mengenai besaran nilai ganti rugi yang perlu mendapatkan kesepakatan diantara kedua belah pihak, yaitu masyarakat dengan pemerintah.

Guna mengakhiri konflik atau perbedaan pandangan dalam menentukan besaran nilai ganti rugi, pemerintah melalui peraturan perundang-undangan menerapkan model lain yakni model jual beli tanah antara pemilik tanah dengan instansi yang memerlukan tanah. Model jual beli ini tentu akan berbeda dengan model pemberian ganti rugi. Pada jual beli kedudukan para pihak adalah seimbang. Pemilik tanah dapat menetapkan harga jual dan pihak pembeli dapat melakukan penawaran harga. Harga jual yang ditawarkan kepada pembeli sudah barang tentu 
Available online at: http://ejournal.unpas.ac.id/index.php/litigasi

Litigasi, Vol. 16(1), 2015, 2781-2804

DOI: http://dx.doi.org/10.23969/litigasi.v16i1.53

akan berpatokan atau berdasarkan pada harga riil atau harga pasar tanah saat itu. Tidak berdasarkan NJOP seperti pada model pemberian ganti rugi. Demikian pula dengan calon pembeli, dalam praktek tidak ada yang memberikan harga penawaran sesuai NJOP, kendatipun NJOP dijadikan juga sebagai dasar untuk memberikan penawaran harga. Dengan model jual beli ini, dari awal harga yang ditawarkan oleh pemilik hak atas tanah merujuk pada harga riil atau pasar sedangkan pada model pemberian ganti rugi, rujukan pertama untuk besaran nilai ganti adalah NJOP. Dengan model jual beli ini tentu akan lebih baik dan menguntungkan bagi kedua belah pihak terutama pemilik hak atas tanah. Dengan kata lain pengadaan tanah bagi pembangunan untuk kepentingan umum tidak akan merugikan pemilik hak atas tanah.

Meskipun model jual beli ini lebih baik dari model pemberian ganti rugi, namun secara hukum model jual beli ini tidak sesuai dengan prinsip hak menguasai negara atas tanah. Hal ini dapat dikemukakan sebagai berikut, akibat hukum dari perbuatan hukum jual beli adalah terjadinya peralihan hak atas tanah dari penjual kepada pembeli. Tanah yang dimiliki penjual akan berpindah menjadi tanah yang dimiliki oleh pembeli. Dengan model jual beli ini negara dalam hal ini instansi pemerintah akan menjadi pemilik hak atas tanah tersebut. Jika tanah yang diperlukan oleh instansi tersebut adalah tanah hak milik, hak guna usaha atau hak guna bangunan maka hak-hak atas tanah tersebut akan menjadi

Copyright @ 2015 , LITIGASI, p-ISSN: 0853-7100; e-ISSN: 2442-2274 
Available online at: http://ejournal.unpas.ac.id/index.php/litigasi

Litigasi, Vol. 16(1), 2015, 2781-2804

DOI: http://dx.doi.org/10.23969/litigasi.v16i1.53

tanah milik instansi tersebut. Padahal negara atau instansi dimaksud bukan subjek hak-hak atas tanah tersebut.

Model atau cara yang harus dilakukan oleh instansi pemerintah dalam melakukan pengadaan tanah bagi pembangunan untuk kepentingan umum sebetulnya sudah jelas diatur oleh UUPA. UUPA telah mengatur hubungan-hubungan hukum antara subjek hukum dengan tanah. UUPA juga mengatur perbuatan-perbuatan hukum antara sebjek hukum dengan tanah. UUPA secara jelas telah mengatur bila subjek hukum memerlukan hak atas tanah tetapi terkena larangan untuk memiliki hak atas tanah tersebut, maka perbuatan hukum yang dapat dilakkukan adalah melalui pelepasan hak dan pencabutan hak.

Akibat hukum perbuatan hukum pelepasan hak dan pencabutan hak adalah hapusnya hak atas tanah tersebut dan tanahnya jatuh kepada negara. Berdasarkan uraian tersebut menurut pendapat penulis bahwa model yang seharusnya dilakukan oleh instansi pemerintah apabila memerlukan tanah bagi pembangunan untuk kepentingan umum adalah bukan dengan cara jual beli tetapi dengan cara pelepasan hak atau pencabutan hak disertai pemberian ganti rugi yang didasarkan pada harga jual beli bukan berdasarkan nilai jual objek pajak (NJOP).

Copyright $\odot$ 2015, LITIGASI, p-ISSN: 0853-7100; e-ISSN: 2442-2274 
Available online at: http://ejournal.unpas.ac.id/index.php/litigasi

Litigasi, Vol. 16(1), 2015, 2781-2804

DOI: http://dx.doi.org/10.23969/litigasi.v16i1.53

Hal tersebut semata-mata dilakukan untuk menghindari terjadinya kemunduran sosial ekonomi masyarakat pemilik tanah, oleh karena itu besaran ganti rugi yang diberikan seyogyanya mengakomodasi prinsip-prinsip jual beli tanah pada umumnya.

Keuntungan yang akan diperoleh dengan model ini antara lain nilai besaran ganti rugi berpedoman pada harga jual beli, adanya kesepakatan mengenai besaran ganti rugi berdasarkan harga jual beli tersebut sudah tentu akan meminimalisasi konflik pertanahan.

Penetapan nilai besaran ganti rugi berdasarkan harga jual beli, juga dapat dipandang sebagai pengakuan hukum dan perlindungan hukum terhadap pemilik hak atas tanah dengan tetap memperhatikan fungsi sosial atas tanah.

Copyright @ 2015 , LITIGASI, p-ISSN: 0853-7100; e-ISSN: 2442-2274 
Available online at: http://ejournal.unpas.ac.id/index.php/litigasi

Litigasi, Vol. 16(1), 2015, 2781-2804

DOI: http://dx.doi.org/10.23969/litigasi.v16i1.53

\section{SIMPULAN DAN SARAN}

A. Simpulan

1. Konsekuensi yuridis pelaksanaan pengadaan tanah bagi pembangunan untuk kepentingan umum dengan cara jual beli sebagaimana diatur dalam UU No. 2 tahun 2012 tentang Pengadaan Tanah Bagi Pembangunan Untuk Kepentingan Umum, Perpres No. 40 tahun 2014 jo Perpres No. 71 Tahun 2012 yang mengakibatkan tanah tersebut menjadi tanah milik pemerintah atau pemerintah daerah adalah bertentangan dengan ketentuan yang diatur dalam Pasal 33 ayat (3) UUD 1945 dan ketentuan UUPA No. 5 Tahun 1960.

2. Model atau cara yang seharusnya dilakukan oleh instansi pemerintah dalam pelaksanaan pengadaan tanah bagi pembangunan untuk kepentingan umum yang sesuai dengan Pasal 33 ayat (3) UUD 1945 adalah melalui proses pelepasan hak dan/atau pencabutaan hak dengan pemberian ganti rugi, seyogyanya besaran ganti rugi tersebut didasarkan pada nilai harga jual beli bukan berdasarkan nilai jual objek (NJOP). 
Available online at: http://ejournal.unpas.ac.id/index.php/litigasi

Litigasi, Vol. 16(1), 2015, 2781-2804

DOI: http://dx.doi.org/10.23969/litigasi.v16i1.53

B. Saran

1. Perlu adanya perubahan ketentuan-ketentuan pasal-pasal dalam setiap peraturan perundang-undangan yang mengatur mengenai pemilikan tanah oleh Negara, karena hal tersebut tidak sesuai dengan Pasal 33 ayat (3) UUD 1945.

2. Dalam pembuatan peraturan perundang-undangan hendaknya memperhatikan sinkronisasi antara ketentuan yang satu dengan ketentuan lainnya, baik secara horizontal maupun secara vertikal. 


\section{DAFTAR PUSTAKA}

Juniarso Ridwan dan Achmad Sodik. 2007. Hukum Tata Ruang dalam Konsep Kebijakan Otonomi Daerah. Nuansa Bandung: Nuansa.

\section{PERATURAN PERUNDANG-UNDANGAN}

Undang Undang Dasar Negara Republik Indonesia tahun 1945 hasil amandemen.

Undang-Undang No. 12 Tahun 2011 tentang Pembentukan Peraturan Perundang-undangan.

Undang-Undang No 26 Tahun 2007 tentang Penataan Ruang.

Undang-Undang No 10 Tahun 2004 tentang Pembentukan Peraturan Perundang-undangan.

Undang-Undang No 32 Tahun 2004 tentang Otonomi Daerah.

Undang-Undang No 4 Tahun 1996 tentang Hak Tanggungan atas Tanah Beserta Benda-benda yang Berkaitan dengan Tanah.

Undang-Undang No 5 Tahun 1960 tentang Peraturan Dasar Pokok-Pokok Agraria.

Peraturan Pemerintah No 8 Tahun 1954 tentang Penguasaan Tanah-tanah Negara.

Peraturan Presiden No. 36 Tahun 2005 tentang Pengadaan Tanah Bagi Pelaksanaan Pembangunan Untuk Kepentingan Umum.

Peraturan Presiden No 65 Tahun 2006 tentang Pengadaan Tanah Bagi Pelaksanaan Pembangunan Untuk Kepentingan Umum.

Peraturan Presiden No. 71 Tahun 2012 tentang Penyelenggaraan Pengadaan Tanah Bagi Pembangunan Untuk Kepentingan Umum.

Peraturan Presiden No. 40 Tahun 2014 tentang Perubahan Atas Perpres No. 71 Tahun 2012 tentang Penyelenggaraan Pengadaan Tanah Bagi Pembangunan Untuk Kepentingan Umum. 
Keputusan Presiden No 10 Tahun 2001 tentang Pelaksanaan Otonomi Daerah di Bidang Pertanahan.

Keputusan Presiden No 34 Tahun 2003 tentang Kebijakan Nasional di Bidang Pertanahan.

Keputusan Presiden No. 55 Tahun 1993 tentang Pengadaan Tanah Bagi Pelaksanaan Pembangunan Untuk Kepentingan Umum.

Peraturan Menteri Dalam Negeri Nomor 1 tahun 2007 tentang Ruang Terbuka Hijau Kawasan Perkotaan.

Peraturan Kepala Badan Pertanahan Nomor 3 tahun 2007 tentang Ketentuan Pelaksanaan Peraturan Presiden Nomor 36 tahun 2005 tentang Pengadaan Tanah Bagi Pelaksanaan Pembangunan Untuk Kepentingan Umum sebagaimana telah diubah dengan Peraturan Presiden Nomor 65 tahun 2006 tentang Perubahan Atas Peraturan Presiden Nomor 36 tahun 2005.

Keputusan Kepala Badan Pertanahan Nasional No 41 tahun 1991 tentang Konsolidasi Tanah Perkotaan.

Surat Edaran Ka. BPN. No 410-4245 tahun 1991 tentang Tujuan dan Sasaran Konsolidasi Tanah. 